\title{
THE CONTIBUTION OF WOLFGANG RICHTER TO CURRENT DEVELOPMENTS IN THE STUDY OF BIBLICAL HEBREW
}

\author{
Hans Rechenmacher and Christo H.J. van der Merve \\ UNIVERSITY OF STELLENBOSCH
}

\begin{abstract}
The aim of the paper is to create a greater understanding of Richter's work without losing sight of its limitations. It commences with a brief description of the background against which Richter's initiatives must be understood. Secondly, the theoretical frame of reference and the basic features of both the morphological, and the morphosyntactic databases he developed are discussed. Some of the prospects these linguistically highly differentiated tools have in store for a better description of Biblical Hebrew are illustrated by means of examples. Thirdly, the theoretical foundations and the structure of the sentence syntactic database which he is compiling are outlined. In conclusion it is pointed out that one may argue that one of Richter's major weaknesses from a theoretical linguistic point of view is his eclectic use of mainly structuralist-oriented principles. However, it will also be illustrated that the practical application of many of these principles does not necessarily jeopardize the usefulness of Richter's databases.
\end{abstract}

\section{Introduction}

In a recent overview of current developments in Biblical Hebrew, the contribution of Wolfgang Richter and his students received little attention. ${ }^{1}$ However, from 1976 to 2002 no fewer than 71 monographs, most of which were inspired by Richter's pioneering work, were published in the series Arbeiten zu Text und Sprache im Alten Testament alone. This series was founded by Richter and is currently edited by three of his former students, Walter Gross, Hubert Irsigler and Theodor Seidl. Although it would be impossible to do full justice to all the research inspired by Richter's approach to the linguistic description of Biblical Hebrew, no overview of current trends in Bib-

1 Van der Merwe (2003: 226-42). 
lical Hebrew linguistics can be representative if at least the main contributions of Richter are not considered. ${ }^{2}$

The primary aim of this paper is to make the results of Richter's work accessible to scholars who, for various reasons, do not appreciate either the results of his meticulous investigation of Biblical Hebrew or the way in which he sets out to do this. Over the last ten years most of Richter's work was conducted in terms of his Biblia Hebraica transcripta project - referred to as $\mathrm{BH}^{t}$. In the framework of this project an elaborate linguistic database was developed in Munich. This article concentrates on this phase of Richter's work. ${ }^{3}$

We will commence with a consideration of the broader frame of reference against which Richter's current work must be understood. We will then proceed to describe the way in which he tagged the Hebrew text at the level of the word, word group and clause. In conclusion we will critically assess the theoretical status of Richter's model and its implications for the usefulness of the database.

\section{General Background}

In an attempt to put Biblical exegesis on a sounder footing, Richter (1971) proposed a structuralist-oriented approach to Biblical exegesis, which he believed would provide scholars with more objectively verifiable results. In this work he already pointed out the inadequacies of the Biblical Hebrew grammars and lexica of his day, for example, the lack of well-defined linguistic categories and clearly defined levels of linguistic description. Since the linguistic description of the Biblical Hebrew text constitutes in many ways the foundation

2 The main contributions of Walter Groß as far as Biblical Hebrew word order is concerned are summarized in Van der Merwe, Naudé and Kroeze. A critical stance towards Groß (1996) is found in Van der Merwe (1999). A succinct summary of Irsigler's research on what he calls 'sentence-binding' with the main categories 'expanded sentence', 'sentence linkage' and 'complex sentence' in Biblical Hebrew is found in Irsigler (1993). For his application of speech-act theoretical analysis to Biblical exegesis, cf. Irsigler (1997).

${ }^{3}$ Van der Merwe (1987: 171-4, 1989: 219-23, 1994: 16-17) provides an overview of the earlier phases of Richter's work. Seidl (1989) considers the influence of Richter's Exegese als Literaturwissenschaft (1971). Riepl (1996 and 1999) described Richter's BHt-Projekt from the perspective of computer linguistics. Disse (1998) scrutinises the structuralist-oriented methodological assumptions that characterize Richter's work. 
on which other exegetical work rests, Richter set out to address this problem. For this purpose he wrote a three-volume work Grundlagen einer althebräischen Grammatik (1978, 1979, 1980), which used insights from the linguistics of his day to develop a model that would help scholars to describe the grammar of Biblical Hebrew more adequately. The formal character of his model, e.g. linguistic categories being defined primarily on the basis of syntagmatic and paradigmatic distributions of their members, paved the way for the use of computer technology to tag, store and retrieve the grammatical data needed for the linguistic description of Biblical Hebrew.

The first step towards the creation of a grammatical database started in 1986. It entails a unique way of transcribing the BHS (Codex Petersburgensis). It is unique in the sense that, although it uses the orthographic system of the Tiberian Masoretic tradition as its point of departure, the transcription aims to account for the morphological and syntactic values contained by each graphical unit (i.e. word). This means the prefixed elements and enclitics

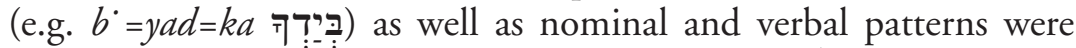
marked and hence retrievable as such (e.g. malk מֶֶ? as qatl-noun pattern).

The entire text of the Hebrew Bible was broken down into clauses and each clause was assigned a label in order to identify its boundaries, e.g. Gen. 1:5a, 5b, 5c, 5d and 5e. ${ }^{4}$ Although no inter-clause relationships were marked, whenever they could be identified on account of the formal features, the following intra-clause items, viz. pendens constructions (e.g. Gen. 6:17aP), infinitive clauses (e.g. Gen. 6:17aI), relative clauses (e.g. Gen. 6:17bR), vocatives (e.g. Gen. 7:1bV) and interjections (e.g. Gen. 22:16bJ), were labeled as such. ${ }^{5}$ In the case of Gen. 6:17 these distinctions imply that the clauses of the verse were marked as follows: $17 \mathrm{aP}+\mathrm{a}+\mathrm{aI}+\mathrm{aIR}+\mathrm{aI}$ and $17 b+b R+b .^{6}$

${ }^{4}$ The criteria for the distinguishing of clauses are explained in Richter (1980:79.50-2).

5 Compare Richter (1991: 1-14) for an explanation of the meta-language and signs used in this databases. Riepl (1996: 561-80) discusses specific problems that were encountered in the process of labeling and encoding the clauses.

${ }^{6}$ Gen. $6: 17 b+b R+b$ means that one of the constituents of $17 b$ is modified by means of a relative clause, e.g. 17b: Everything 17bR: which is on earth 17b: will perish. 


\begin{tabular}{|c|c|}
\hline $17 \mathrm{aP}^{7}$ & 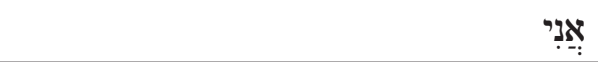 \\
\hline a & 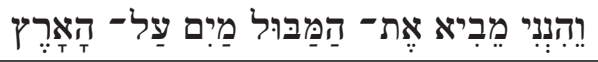 \\
\hline aI & 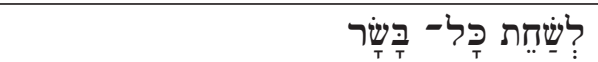 \\
\hline aIR & 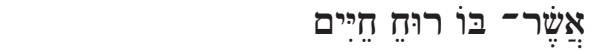 \\
\hline aI & 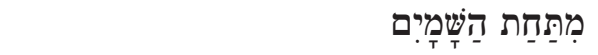 \\
\hline $\mathrm{b}$ & ذذל \\
\hline bR & 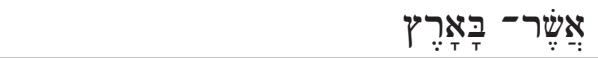 \\
\hline b & 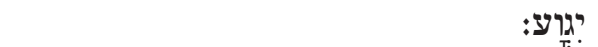 \\
\hline
\end{tabular}

Just the encoding of the transcribed text in itself already provided a 'first generation' of data that could be manipulated electronically, e.g. the investigation of noun and verbal patterns, pendens constructions, ${ }^{8}$ and the compilation of concordances which display constructions in the context of the clause in which they occur.

\section{Word Level}

In the grammatical model Richter developed for the systematic description of Biblical Hebrew, he distinguishes four levels of description (word, word group, clause and clause combinations). In accordance with this hierarchical model the grammatical analysis commences with the morphological parsing of each morphological unit. For this purpose a computer program called SALOMO ${ }^{9}$ is used to read and process the textual data. SALOMO uses grammatical rules based on already processed data to propose parsings for newly pre-

7 In this table only the divisions of the clauses are illustrated. For the explanation of the theoretical frame of reference, and examples of the proposed transcription, cf. Richter (1983) and (1991).

${ }^{8}$ For example, a researcher who is interested in the (theologically so important) syntax of Gen. 1:1-3, in particular the use of the pendens construction in verse 1 of which the domain covers more than one verse, could easily compile 35 similar examples of pendens constructions plus their domains (stretching over more than one verse) and thus invalidate an important argument for the defenders of the traditional interpretation of Gen. 1:1 as independent clause. Cf. Rechenmacher (2002: 6).

9 Eckardt (1987) provides insight into the structure and procedures carried out by SALOMO. Most of the grammatical rules used by SALOMO are based on Richter (1978). 
sented data. The proposed parsings are verified by experts (i.e. Richter and his team). In the case of ambiguous or problematic constructions, they may draw on their wider knowledge of Hebrew morphology or even the high levels of syntax and semantics to arrive at adequate solutions. The new data, as well as constructions reflecting rules that have not yet been included in the system, are then incorporated into the database. The morphological database developed in this way from the preposition $b^{\circ}$ in Gen. $1: 1$ to $y i^{\circ} l$ in 2 Chron. $36: 23$ contains 489,422 notations. The Hebrew version of Sirach has a further 15,386 notations.

The morphological data compiled by means of SALOMO were revised from various points of view.

a) Noun patterns: With the complete data available at this stage, systematic investigations into structural noun patterns were conducted. That again led to corrections of the data.

b) Semantic notations: Semantic values were attached to lexemes, in particular those semantic values of lexemes that may have syntactic implications. As far as verbs are concerned, the semantic value [to give] will be attached to the lexeme $n t n$, or [to go] will be attached to hlk. The semantic values attached to these lexemes are relevant since there is a correspondence between these values and the syntactic patterns, prompted by the respective verbs: ${ }^{10}$

1. $P($ give $=$ verb $)+1 . S y($ he $=\mathrm{NP} /$ subject $)+2 . S y$ (the food $=$ $\mathrm{NP} /$ object with object marker $+3 . \mathrm{Sy}$ (to the people=PP/indirect object with preposition), versus

2. $\mathrm{P}(\mathrm{go}=\mathrm{verb})+1 . \mathrm{Sy}(\mathrm{he}=\mathrm{NP} /$ subject $)+6 . \mathrm{Sy}($ to Tarsis $=\mathrm{PP} /$ prepositional object).

As far as nouns are concerned, the following oppositions play a central role: [concrete]:[abstract], [individual]:[collective], [living]:[non-living], while the following often also need to be considered [place], [time], [body part], [instrument], [building], etc. These distinctions are made because they may correlate with morphological distinctions; cf. the discussion on p.xxx of the morphological data recorded in the fields 18-24.

c) Homonyms are distinguished. Here the shared Semitic root in contrast to the inner Hebrew base plays a significant role. bahür in Eccl. 11:9aV and Ps. 89:20d is a good example. The base and the noun pattern are identical, but two lexemes must

${ }^{10}$ Cf. p. xxx for a list of the sentence constituents Richter distinguishes. 
be distinguished, viz.: bah̄ur 1 'youth' (root $B H R$ ) and bah̄ur 2 'preferred or chosen one' (root BHR).

d) When the morphology was revised in the light of the analysis and categorization at the level of the morphosyntax, it led to insights that required that the morphological categorization had to be supplied with complementary information, as far as word class, gender and number are concerned. So, for $b a b \bar{u} r$ in Ps. 89:20d it was necessary to indicate that this participle functions in a word group as a substantive. (This type of information is encoded in field 35.) In a similar way it was necessary to indicate that in Gen. 28:22a the morphosyntax requires a feminine (syntactic gender) for אבק 'abn in contrast to its morphological masculine gender.

Furthermore, it was found that the morphological and semantic analyses of proper nouns require a specialized type of study. For this reason the results of this analysis have been kept apart. However, they can be retrieved like all the other text data. The proper nouns were described in terms of the same theoretical frame of reference as all the other data, and for this reason can be accessed in conjunction with any other type of search. ${ }^{11}$

However, in order to fully appreciate the value of all the dimensions and capabilities of the database of the word level, a brief look into its structure may be helpful. We will first give an overview of the global structure and then look more closely at the entries themselves.

Each of the 489,422 entries has 45 fields of information, viz.

1-9: $\quad$ Indication of book, chapter, verse and clause within which an entry occurs, as well as other position markers

10: $\quad$ אִרץ $\quad$ The entry itself, e.g. 'arș (a transcription of

11-13: Person, status, gender and number

14-17: $\quad$ Ending of word and extensions

18-24: $\quad$ Stem modification and pattern type ('Bautyp')

25-31: $\quad$ Base form and root

32-3: $\quad$ Lexeme

34: $\quad$ Word class

35-9: $\quad$ Level-specific change of word class, gender and number

40-3: $\quad$ Semantics

44: $\quad$ Language

45: $\quad$ Commentary

11 Cf. Richter (1996). 
This highly differentiated grid for describing each of the entries was developed in order to make very sophisticated searches possible. The new horizons this opens for the morphological description will be evident from the following 4 examples, where we zoom in first on fields 18-23 (i.e. stem modification and type of pattern), and then field 44 (i.e. language):

\begin{tabular}{|c|c|c|c|c|c|c|c|}
\hline & & 18 & 19 & 20 & 21 & 22 & 23 \\
\hline$r \bar{e}('){ }^{r} \bar{s} t$ & רֵאשִׁית & 0 & $1 \mathrm{i} 23 \mathrm{It}$ & 0 & 1i23:I:t & 0 & 0 \\
\hline 'arș & אֶרְץ & 0 & $1 \mathrm{a} 23$ & 0 & 0 & $\mathrm{p} 4-3,5-1$ & 0 \\
\hline himțīr & הִמְטְיר & $\mathrm{H}$ & hi12I3 & 6 & hi:12I3 & 0 & 0 \\
\hline rašst & רְשֶׁת & 0 & $1 \mathrm{a} 2 \mathrm{t}$ & 0 & $1 \mathrm{a} 2: \mathrm{t}$ & 0 & $2 \mathrm{a} 3 \mathrm{t}$ \\
\hline
\end{tabular}

Field 18 allows the encoding of the stem modification of the four lexemes in our corpus (They come from Gen. 1:1; 1:2; 2:5 and Exod. 27:4 respectively). However, only himtīir is assigned a value, viz. that of $\mathrm{H}$ referring to the $\mathrm{H}$-stem (Hiphil). The other examples have a zero value, since they are not verbs. Only verbs have stem modifications.

Field 19 allows the description of the pattern (Bautyp) of the lexeme involved. The base radicals are represented by a system of numbers. For this reason, instead of the traditional qatl pattern, the code $1 a 23$ is used to describe the pattern of 'ars. Long vowels are indicated by means of capital letters. Such a system guarantees both transparency and consistency. In the case of dit $(1 \mathrm{Kgs} 7: 14 \mathrm{c})$ the code reads: 2i3t. This code indicates unambiguously the second and third base radical as well as the ending $-t$ which the consonants of the lexeme represent. Traditionally this pattern is depicted as qil with a feminine ending. ${ }^{12}$ However, this creates the false impression that the first $(q)$ and third $(l)$ base radicals come into play. This could be avoided by using tilt instead of qil + feminine ending. But then it remains uncertain whether the second $t$ is a closing or duplicated

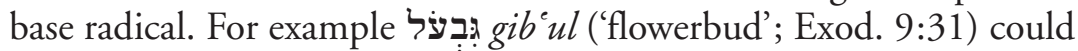
traditionally be presented only ambiguously, viz. qitlul, which could be 1 i23u3 or 1 i23ul.

Field 20 allows the description of the functional value that is associated with a particular pattern type. Of the four entries in our corpus, only himtitir can be assigned a function value, i.e. ' 6 .' This ' 6 ' is

${ }^{12}$ Compare for example Bauer-Leander (1922: 450, \$61j) 
an index number for the denominative character of the pattern type hi12I3. Other values would be ' 1 ' for typical patterns of nomina actionis, e.g. $12 A 3 A$ in 'ibōd $\bar{a}$ 'work', or '2' for typical patterns of nomina agentis, etc.

Field 21 also describes features of pattern types. In this field the features of the individual elements of the pattern types are described. This is necessary when a pattern type displays a prefix, infix and/or suffix. A colon is used to indicate where the prefix, infix or suffix starts or/and ends. Thus, hi in hil2I3 is marked as such. It renders the code hi:12I3. The feminine :t in li23It and, finally, the long vowel $: I$ which forms together with the feminine :t the :I:t-ending responsible for the abstract content of the whole lexeme, renders the code: 1i23:I:t. These distinctions are necessary if one would like to search for pattern types with particular prefixes, infixes or suffixes.

Field 22 allows the description of lexemes which have a singularplural or other type of opposition in their pattern types. A good example in this regard is 'ars. The index number p4-3, 5-1 indicates that a twofold opposition is involved: 1. (4-3) the opposition in pattern type, viz. qatl in singular and qatal in the plural ('arasōt). 2. (51) the opposition in gender, viz. masculine vs. feminine. ${ }^{13}$

Field 23 again allows the description of pattern type alternatives. In the case of rašt in our corpus it is, for example, not clear whether the base radicals are $r \check{s}$ or $w r \check{s}$. For this reason the possible alternatives are described in this field.

The fine distinctions made in fields 18-23 allow the following type of searches: 1 . Find all base forms in the D-Stem that realize a denominative function. 2. Find all lexemes where the pattern type qatl displays morphologically a masculine-feminine opposition in the plural. 3. Find all pattern types that are formed with the $i t$-suffix. Sort them as [+abstract] versus [-abstract]. The latter is semantic information encoded in fields $40-43 . .^{14}$

Next we look more closely at the information encoded at field 44, language. This field has the label 'language' and in it is recorded whether one or other feature of a lexeme can be related to another language.

13 The notion masculine vs. feminine applies here only to the form of the pattern type (morphological gender).

${ }_{14}$ Richter (1998) represents an exhaustive list of the noun forms described in the Munich database. Richter (2002) treats the verb forms it contains. An example of a study of a particular noun form and its etymology by means of the Munich databases is Rechenmacher's study (1996) of the lexeme šabbat $[t]$. 


\begin{tabular}{|c|c|c|c|}
\hline$\left.r \bar{e}()^{\prime}\right) \bar{s} \bar{i} t$ & רֵאשִׁית & (Gen. 1:1) & fh \\
\hline $\operatorname{yakk}[\dot{i} t] t \bar{u}$ & יָכְּתוּוּ & (Dt. 1:44) & fh:f1-7 \\
\hline baqqārat & בַּקָרַת & (Ezek. 34:12) & fh:f1-3 \\
\hline hart ${ }^{\circ} u m$ & חַרְטִם & (Dan. 2:10) & fa:f9-2 \\
\hline
\end{tabular}

The notation fh indicates whether a Hebrew, and fa whether an Aramaic text, is involved. This notation followed by a colon and code that indicates whether a lexeme show signs (or traces) of influence from a foreign language, e.g. $\mathrm{fl}$ (in fh:f1) indicates an Aramaic influence, f9 (in fa:f9) indicates an Egyptian influence. The number after a hyphen points to the specific aspect of a lexeme that shows traces of a foreign influence, viz. (-1) it is the radicals and pattern type; in such cases a full-blooded loanword is involved, (-2) only the radicals, $(-3)$ only the noun forms, (-4) only the grammatical morpheme, (5 ), only the occurrence of dissimilation, (-6) only the orthography and (-7) only the verbal form.

The first example $\left.r \bar{e}()^{\prime}\right) \bar{s} t$ is completely unproblematic. This means that it occurs in a Hebrew section of the Bible and it has no traces of the influence of a foreign language. Hence the notation: fh.

yakk[it]tū (Base form: $k t t$ ) also comes from a Hebrew section of the Bible, hence the notation fh. The notation $\mathrm{f} 1-7$ indicates Aramaic influence as far as the verbal form is concerned. (Compare the formation of geminate verbs in Aramaic, where the gemination of the first radical is a regular feature of the prefixconjugation of this verb class. The standard pattern in Biblical Hebrew by comparison does not have this gemination, e.g. yisub[b].)

baqqärat (in the status constructus) is an example of an Aramaicized noun form. 1a22A3A is in Biblical Aramaic the regular infinitive form of the Piel (D-Stem). In the case of Ezek. 34:12 the form used is a substantivized infinitive form. ${ }^{15}$

The last example, hart ${ }^{\circ} u m$, comes from the Aramaic part of the Bible (fa). The radicals are borrowed from Egyptian, while the pattern type, orthography and inflection (plural) follow the rules of the Aramaic system.

This type of notation concerning the identifiable traces in Hebrew lexemes of the influence of other languages makes a range of search requests possible. One comprehensive type of research project could be a study of the influence of Aramaic on Biblical Hebrew, based on

${ }_{15}$ Compare also bahhāla, baqqaš̌a, na"āṣa, und naḥ̣ālā. 
a systematic retrieval of fh:f1-*, which would produce all Aramaicinfluenced forms of Biblical Hebrew, differentiated according to the point of influence (radicals, patterns, morphemes, etc.).

These efforts of Richter contributed to the establishment of an academically well-justified linguistic database for Biblical Hebrew at the level of words. It can be regarded as well-justified, since each of the words of the Hebrew Bible is classified in terms of clearly defined formal criteria. These criteria are based on the entire Hebrew Bible and refined from various points of view. Furthermore,

- Apart from the canonical books, the Hebrew version of the book of Sirach is also included. ${ }^{16}$

- Mistakes in the database have been minimized by the cooperation between scholars that have been using the data for several years. Mistakes and inconsistencies were reported on a regular basis. These reports often led to computerized consistency checks.

- The methodological perspectives that were used to describe the data go well beyond those of the traditional approach.

- It also makes the testing of new perspectives possible. The attempt to identify sets of relevant semantic classes with which verbs and nouns could be tagged is a good example in this regard.

\section{Level of words groups}

Biblical Hebrew grammars and concordances of the Hebrew Bible can provide one with reliable information, although often only partial, about the morphology of Biblical Hebrew. However, what does not exist is reliable linguistic information about higher levels, i.e. the level of word combinations, clause syntax and clause formations. By reliable information is meant information that is based on the analysis of comprehensively collected data. Apart from the above-mentioned sophisticated morphological database, Richter and his team also recently completed a database which contains a description of each of the word combinations that occur in the entire Hebrew Bible and the book of Sirach. This means all the word combinations in this corpus are analysed and categorized in terms of a set of formal criteria. ${ }^{17}$

${ }^{16}$ The integration of the old Hebrew epigraphical material is also planned. Richter has already provided the transcription, published in Richter (1999).

${ }_{17}$ Richter (2000) provides the results of this major project in the form of printed lists of the various word combinations. 
This project was undertaken with the help of the expert system AMOS. AMOS uses the morphological analysis as input and analysed it with the help of a system of morphosyntactical rules to produce a set of ASCII data. ${ }^{18}$ This set of data displays the bi-polar formations or the hierarchically structured sets of bi-polar formations in the form of linear texts in bracketed bi-polar formations or combinations of bracketed bi-polar formations.

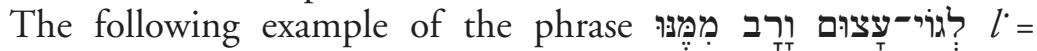
gōy ${ }^{\circ} a s \bar{u} m$ wa $=r a b[b]$ mim-min $=[h] u(w)$ '(to) a nation mightier and greater than they' illustrates these different formations. ${ }^{19}$

(“Dt. 9:14d.0” 411

(PV (PRAEP “l”)

(ATTV (SUB “gōy”)

(ANNV/ABS/ (KOORDV (ADJ “eașūm”)

(KONJS (KONJ “wa”)

$(\mathrm{ADJ}$ “ $\mathrm{rab}[b] ")))$

(PV (PRAEP “mim-min”)

$(\mathrm{EPP} “[h] u(w) ”))))))$

The word combinations in the above-mentioned phrase can be displayed by means of a tree diagram:

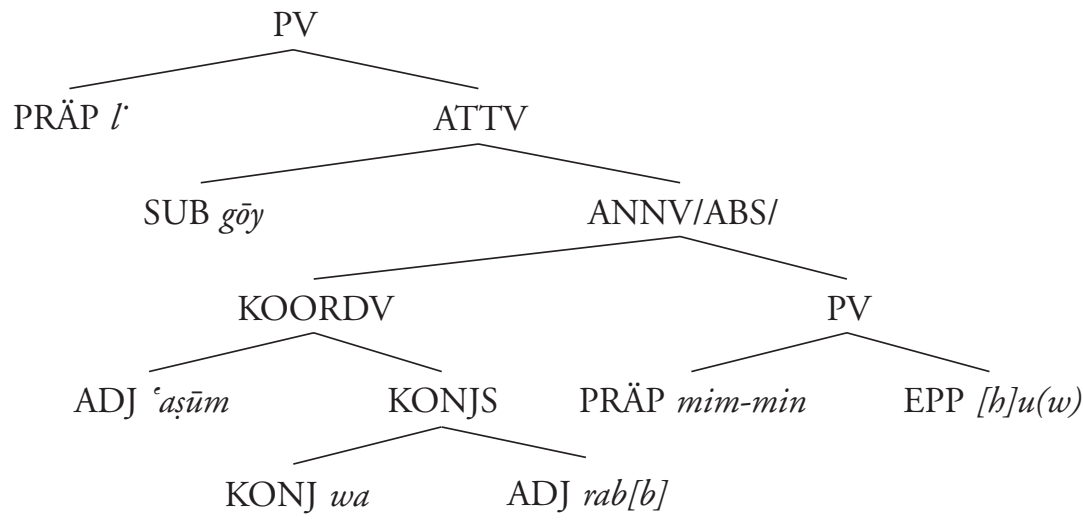

18 AMOS is described in Specht (1990). The basis of the system rules is Richter (1979).

19 The place markers encode in addition to the book, chapter, verse, clause also a clause fragment number, which is crucial in the case of split clauses, and two position markers to determine the position of a word group in a clause (e.g. 411 in Dt. 9,14d means that the analyzed word group stands between space 4 and space 11 of that clause; 'space' here refers not only to the graphic blanks in the Hebrew Bible but also to the slits between enclitic elements and the noun / verb).

The abbreviations must be understood as follows: $\mathrm{PV}=$ prepositional word group, 
The above word group was chosen as an example because it cannot be represented directly in languages like English and German where the adjective precedes the noun. In translation the attribute must be presented by means of an appositional construction or a relative clause (e.g. the NRSV translates 'a nation mightier and more numerous than they').

At the level of word groups this database allows interesting types of searches, e.g. when the use of min with a comparative function within an attributive word group needs to be investigated, a simple search command will render 33 word groups.

Furthermore, if one considers the combination of word groups

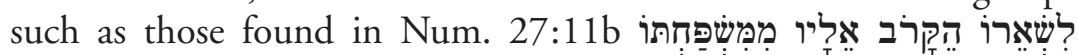

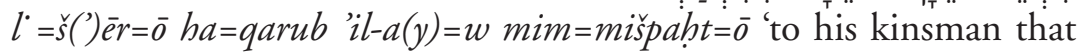
is next to him of his family', it is evident that this database allows the systematic description of hitherto unnoticed structural characteristics of Biblical Hebrew, viz. two preposition word groups are dependent on a single adjective. In English the attributive word group has to be translated as a relative clause. One may argue that this type of investigation may lead to the rebuttal of literary critical arguments that often regard these types of constructions as 'unusually long' or 'clumsy' and hence later additions. The literary arguments referred to normally arise from the influence of the scholars' mother tongues rather their knowledge of the structure of Biblical Hebrew. ${ }^{20}$

\section{Level of Clauses}

Currently data at the clause level are being analysed and classified. Since the lower levels of grammatical description all relate to this level, it occupies a central place within the Biblical Hebrew grammatical system. Notwithstanding, the analysis and classification of data at this level are often neglected in the traditional grammars, e.g. in most of these grammars not all the clause constituents are adequately categorized, nor is their combination potential systematically described. ${ }^{21}$

PRAEP = preposition, ATTV = attributive word group, $\mathrm{SUB}=$ substantive, ANNV/ABS/ = Annexions word group (this word group looks like a construct word group but has an adjective or participle as Nomen regens) with dominant word in the Status absolutus, KOORDV $=$ Coordination word group, $\mathrm{ADJ}=\mathrm{Ad}-$ jective, $\mathrm{KONJS}=$ Conjunction syndese, $\mathrm{EPP}=$ enclitic personal pronoun

${ }^{20}$ For more examples of the use of the database at the level of word groups, cf. Vanoni (1996) and Rechenmacher (2003).

${ }^{21}$ Richter (1978: 21, note 50) observes: 'How little grammarians understand of 
The theoretical frame of reference for the description of clauses is provided by the concept of 'valency'. It is based on the insight that words, and in particular verbs, determine the structure of a clause.

The input for this level of description is the word classes of the morphology and the word combinations of the morphosyntax. The words or word combinations are described as clause constituents on account of the relationship they have with the verb and other constituents of the same clause. Also used are: lists that classify all nominal clauses as one or other clause type ${ }^{22}$ lists that classify all infinite constructions on account of the preposition introducing them, their syntagmatic value in the matrix clause (i.e. subject/Sy1, object/Sy2, etc.) as well as their semantic value (e.g. comparative, final, explicative, etc.).

Richter discerns 14 types of syntagmemes. The following list may illustrate his scheme. (The Hebrew examples are all from Genesis. The respective syntagmeme is underlined):

$\mathrm{P} \quad=$ Predicate; $1: 28 w a=y \overline{0}\left({ }^{\prime}\right)$ mir la $l=h i m$ 'il $\bar{o}^{*}$ hìm

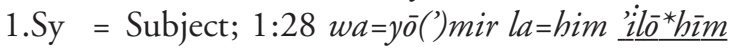

2.Sy = direct Object, also direct speech and object clause; 1:7 wa=yi ${ }^{\imath}$

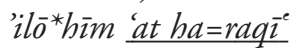

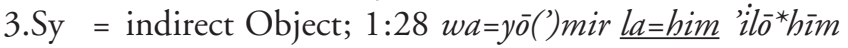

4.Sy = prepositional Object; 3:16 $w^{\circ}=h \bar{u}\left({ }^{\prime}\right)$ yimšul $\underline{b-a=k}$

5.Sy = locative; 9:27 $w^{\circ}=$ yiškun $\underline{b^{\circ}={ }^{\prime} \text { uhüle } \breve{S} M}$

6.Sy = dislocative; 3:19 $w^{\circ}$ "'illapar tašüb

7.Sy $=$ infinitive as predicate content; 4:2a $w a=t \bar{o}^{*}$ sip $\underline{\text { la } a=l i d t}$ ' $^{\prime} t$ $\underline{a} h \bar{\imath}=w$ 'at $H B L$

8.Sy = advantage/ disadvantage; $32: 8$ wa $=y i s a r[r] \underline{l} \underline{\underline{0}}$

9.Sy = ambit; 16:5 wa='iqal[l] $\underline{b^{\circ}={ }^{e} \bar{e} n \bar{e}=h a}$

10.Sy = comparative; $38: 26$ sad qa mim-min $^{\circ}=\bar{\imath}$

11.Sy = agent in passive; $31: 15 h \dot{h}=l \bar{o}\left(w^{\prime}\right) n u k r \underline{{ }^{*}} y^{\circ} \bar{o} t$ nibš ${ }^{\circ} a b n \bar{u} \underline{\underline{l}=\overline{0}}$

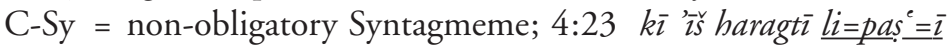

Adnominal = like C-Sy non-obligatory Syntagmeme, however, not relating to the clause as a whole, but to one specific syntagmeme only; 25:8 wa=yamut 'BRHM $b^{\circ}={ }^{\prime}=\dot{s} \bar{b} \bar{a}$ tōbo zaqin

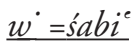

the importance of this level of description is implied by the fact that they do not even have a technical term for it'. ('Die Bedeutung dieser Ebene lässt sich den Grammatiken nicht hinreichend entnehmen, was sich schon am Fehlen eines Terminus zeigt.')

22 Nominal clauses include participle clauses, existence clauses and nominal clauses modified by hyy. 
Each clause (also relative clauses and each clause-like participle and infinitive construction) is tagged with regard to the following: 1) the clause construction pattern ('der Satzbauplan'), 2) modifications of the kernel clause (i.e. the optional syntagms [clause constituents], conjunctions, modal words, deictics, interjections, vocatives and infinitive absolutes). The syntagms of the kernel clause as well as all the modifications according to the type and number are listed and their position in the clause indicated. Pro-elements (i.e. pronouns, deictics and adverbials) are 'resolved' (i.e. clause and position where the referent of the pro-element can be found are specified); in the same way cases of contextual ellipsis are marked as such. Each syntagm is also assigned a basic semantic value. In the case of passive and idiomatic constructions the deep structure of the relevant clause is described next to that of the surface structure. Here are two examples:

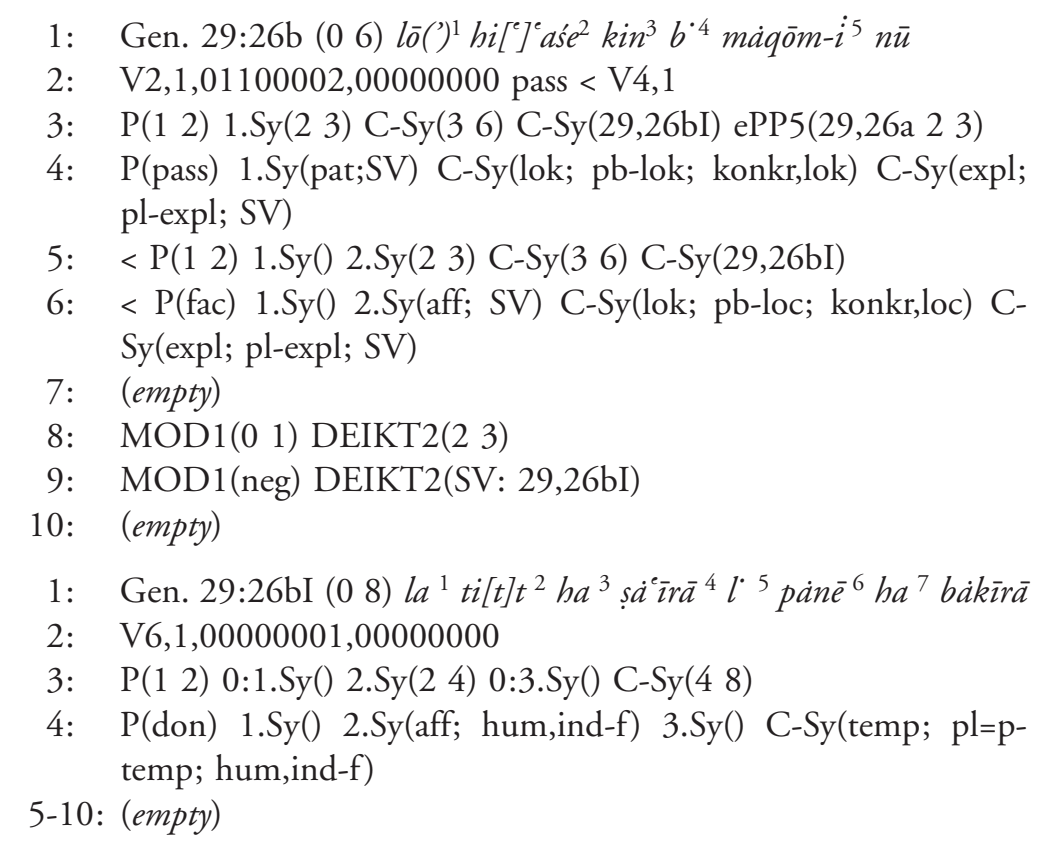

Each table has 10 lines:

Line 1 indicates the passage and the number of spaces, e.g. ( $\left(\begin{array}{ll}6\end{array}\right)$ means 6 spaces confining 5 units (words or pro-/enclitic elements). Especially when it comes to split clauses (cf. above Gen. 6:17b) or clauses exceeding one single verse (cf. Gen. 10:11b+12v), this line is important to make clear what exactly is covered and how the positions are counted. 
Line 2 gives the clause construction pattern and describes the number and type of elements in addition to the kernel clause. In the case of Gen. 29:26bI the following is indicated:

$\mathrm{V} 6,1$ indicated the $\mathrm{V}$ (erbal clause) pattern, viz. $\mathrm{P}+1 . S y+2 . S y+3 . S y$, and 00000001 (first eight digit block) indicates that there is only one Circumstantial modifying the kernel clause (cf. 26b with 01100002, indicating one deictic, one modal particle and two Circumstantials). The second block (i.e. 00000000 following 01100002 in line 2) is reserved for elements that are omitted but operate in the frame of 'sentence-binding'. ${ }^{23}$ In Gen. 29:26b nothing relevant can be recorded. However, in Gen 28:6 the double-duty conjunction $k i$ in Gen. 28:6 operating both for $6 \mathrm{~b}$ and $6 \mathrm{c}$ need to be indicated in this block.

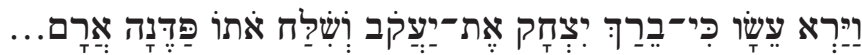

In $26 \mathrm{~b}$ the passive construction is indicated as well as the clause construction pattern of the respective active structure.

Line 3 lists all syntagmemes with their positions, including the Circumstantials. In 26b, for example there is the C-locale $b^{\circ}=m \dot{a}$ $q \bar{o} m-i=n \bar{u}$ with the position space 3 until space 6 and the $\mathrm{C}$ explicativum 26bI. In this line pronouns and other pro-elements are also dissolved, in $26 \mathrm{~b}$ the enclitic personal pronoun at the position 5(-6). It stands for Laban (mentioned in clause 29:26a, position 2-3) and an indefinite collective (prompting the plural!), of which he is part. The omitted 1.Sy and 3.Sy in 26bI are not to be understood contextually. Both cases are so-called 'Nullwert'. They have no clear contextual or situative reference. Rather the ellipses could be replaced by indefinite pronouns without changing the proposition in substance.

Line 4 describes the functional values (e.g. [pass(ivum)] for the predicate in 26b and [aff(ectum)] for the 2.Sy/direct object in 26bI) and basic semantics of the syntagms (e.g. [hum(anum), ind(ividuativum)-f(eminum)] for $h a=s \dot{a}^{-} \bar{i} r \bar{a}$ in 26bI and [konkr(etum), loc(us)] for $m \dot{a} q \bar{o} m-i=n \bar{u}$ in 26b. SV in 26b is the abbreviation of German Sachverhalt and refers to a proposition. For PP the governing preposition is indicated by a code ('pb' indicates the preposition $b^{\circ}=$, ' $\mathrm{pl}=\mathrm{p}^{\prime}$ indicates the preposition $l^{\prime}=$ pane $\bar{e}$ etc.) and also semantically classified: [loc(al)], [expl(icative)],[temp(oral)].

23 The term 'sentence-binding' (equivalent of German Satzformen) was coined by Irsigler. It refers to the binding of clauses by double-duty elements. Cf. Irsigler (1993: 84-96). 
Line 5 and Line 6 are reserved for deep structures of passive and idiomatic constructions (cf. 26b).

Line 7 lists syntactical free elements like interjections and vocatives.

Line 8 and Line 9 describe the type, position and function / semantics of particles; for $26 \mathrm{~b}$ we have the modal particle $l \bar{o}\left({ }^{\prime}\right)$ (subclass $1=$ epistemic particle, here: function [neg(ation)] and a deictic kin (subclass 1 = text deictic, operating on text level, here referring primarily to 26bI, but also back to the whole narration in chapter 29).

Line 10 would be the place for comments.

The semantic description on this level would also be an important module for creating a comprehensive valency lexicon, cf. the exemplary study of Nissim (2000).

\section{Level of Clause Syntax}

A first generation of observations at this level is being systematically described. Phenomena at this level come into play when the valency of a verb extends beyond the border of a clause, e.g. in the case of direct speech, or constructions with an object clause, etc. It is furthermore accepted that the classification of the conjunctions plays an important role in the determination of clause relationships. Possible values, as a preliminary exercise, are therefore assigned to the conjunctions. Konj $j_{1}$ would be simple connective as in clause sequences with $w^{\circ}=$, Konj $j_{2}$ would be still coordinating, but with a thetic nuance, e.g. contrastive, as $w^{\circ}=$ in Gen. 27:11b-c, also Konj ${ }_{3}$ : coordinating but with a semantic-logical relation of subordination, e.g. $k \bar{\imath}$ in Gen. 31:15b, Konj ${ }_{4}$ for correlative function, e.g. $k^{\prime} \ddot{y}=\mathfrak{a}^{\prime} \mathrm{s}_{r}$ in Gen. 50:6d, Konj ${ }_{5}$ for syntactical subordination as e.g. $k \bar{\imath}$ in Gen. 50:15b, finally $\mathrm{Konj}_{6}$ for main clause as e.g. in Gen. 25:45b. The research of Irsigler on 'sentence-binding' is used to identify and mark expanded sentences, sentence linkage and complex sentences. ${ }^{24}$

The analysis and classification of data at the level of the clause and clause combination level has commenced only recently (January 2002). The chances are small that the tagging of the entire corpus will be completed before 2005 .

${ }^{24}$ Cf. the respective taxonomy by Irsigler (1993: 84-96). 


\section{Critical Evaluation}

If one tries to evaluate Richter's work critically, one could ask various questions, questions which, of course, are determined by one's own theoretical frame of reference or by one's own scholarly interests and/ or field of study. ${ }^{25}$ We would like to view Richter's work in terms of what he himself set out to do, viz. putting the linguistic description of Biblical Hebrew (or Old Hebrew as he prefers to call his object of investigation) on a scientifically sounder footing. This he deemed necessary because the relatively little Biblical Hebrew data at our disposal were described for many years in most Biblical Hebrew grammars in terms of inadequate notional categories.

To address this problem all the available Biblical Hebrew data had to be described in more adequate categories. Adequate categories for him are categories of which the criteria are formalized in terms mainly of distributional criteria. However, he is not ideological in this regard, since at each level of linguistic description functional values also come into play. ${ }^{26}$ Most important, though, is the fact that the criteria for determining the membership of each category must be unambiguous. A good example in this case is the traditional word class 'adverb'. Adverbs certainly do not share the homogeneity of the morphological features of verbs and nouns. Furthermore, even on the basis of distributional criteria alone, one may end up with assigning such a diverse array of lexemes to one and the same class so that the usefulness and/or the empirical status of such a broad category may be called into question. ${ }^{27}$

In order to obtain a more adequate set of grammatical categories of the description of Biblical Hebrew, Richter (1978, 1979 and 1980) developed an explicit provisional theoretical frame of reference before he started his exhaustive analysis of Biblical Hebrew. In these works he scrutinized the existing descriptions of Biblical Hebrew and, where necessary, proposes new sets of grammatical categories. Although these new categories appear to many Old Testament scholars as idiosyncratic

25 According to De Beaugrande (1984: 40-1), Richter's model would be one with a logical appeal. In this type of model, De Beaugrande claims, 'the investigator's own reasoning (classifying, categorizing, asserting) was the primary mode of discovery ... In the empirical or operational perspective, on the other hand, discovery hinges upon seeing how something works and building a model of that.'

26 This means that meaning has not been banned from his grammatical description of $\mathrm{BH}$. This was propagated in most American structuralist circles of the 1950s.

27 Cf. Schwarz's (1982) publication: ,Was ist ein "Adverb"? 
creations of Richter, many of the 'new' word classes he distinguished were already used in the descriptions of German and English grammars of the $1980 \mathrm{~s}^{28}$ It is also important to realize that despite the fact that these new categories were informed by the grammatical description of other languages, each had a preliminary character. They were refined in the light of analysis of all the Biblical Hebrew data available. Compare, e.g. the list of modal particles distinguished in Richter (in 1978) and the one used in the most current version of his morphological database. ${ }^{29}$ One may argue that the current list does not only have heuristic value. It also has an empirical status as far as Biblical Hebrew is concerned. It certainly represents a well-defined set of categories that could be used to debate the status of word classes across languages, in particular for use in corpus linguistic studies.

Apart from the analysis and classification of the categories normally associated with Biblical Hebrew morphology, Richter's highly differentiated grid for the notations of base forms, roots and affixes, and the values that may be attached to them, opens new horizons for lexicographical and comparative philological descriptions of Biblical Hebrew. In comparison with the structure of Talstra's database (Talstra and Sikkel 2000) at the level of morphology, Richter's allows much more nuanced searches as far as the historical dimensions of the lexical stock and some morphological features of Biblical Hebrew are concerned.

An exhaustive systematic analysis and description of the word combinations of Biblical Hebrew have not yet been undertaken. Richter's morphosyntactic database gives an impetus to the description of this much neglected aspect of Biblical Hebrew. As in the case of the morphological database, the development of this database started with the formulation of a preliminary set of categories (Richter 1979) that were refined in the light of the process of analysis and tagging of all the available Biblical Hebrew data. Although some scholars may prefer to work exclusively with surface-level criteria at this level (e.g. Talstra and Sikkel 2000) and may question the need to lump together combinations that have different surface level features under one word group (e.g. Appositional word group covering struc-

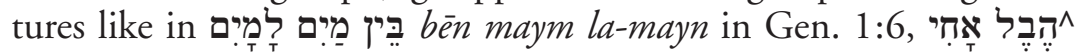

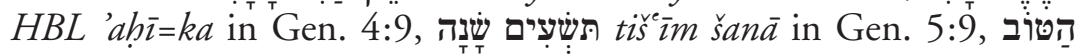
דִ ture of Richter's database allows the systematic retrieval of surfacelevel combinations within a specific word group.

28 Cf. van der Merwe (1993). 
If one considers Richter's theoretical frame of reference at the clause level, one is confronted with a set of labels (e.g. 1.Syntagm, 2.Syntagm, etc.) that indeed appear to be idiosyncratic. However, if one understands that these labels could be extremely useful for the lexical analysis of Biblical Hebrew or that they could easily be mapped onto more conventional categories (e.g. subject, complement, and adjunct), they soon lose their idiosyncratic appearance.

Richter's databases are not only hierarchically structured and therefore allow the accessibility of linking information between the different levels of description, but his approach also allows the tagging of information at the 'higher' levels of linguistic description, e.g. that of sentence syntax, semantics and pragmatics. This means, for example, that experiments are possible with sets of tags/categories from various theoretical frames of reference. How this should or can be done, Richter himself does not speculate on. In comparison with the database developed by Eep Talstra (Talstra and Sikkel 2000), Richter's databases are at this stage more focused on the grammatical and lexical description of Biblical Hebrew than Talstra's. The Talstra aimed from the outset to create an electronic database that could be used to describe the text-linguistic dimensions of Biblical Hebrew.

In conclusion two possible objections against Richter's work need to be considered:

(1) The first concerns the many decisions that influenced the structuring of the raw data and the types of analyses that were undertaken. These decisions are typically the vehicles that introduce the subjective perspectives of a researcher into the instrument he/she develops. ${ }^{30}$

(2) The second concerns the orientation of the databases in the light of theoretical linguistics.

As far as (1) is concerned, it represents an inevitable problem that no researcher can escape. Its negative implications can only be reduced if the researcher takes great care that similar phenomena are

${ }^{29}$ In Richter (1978: 192) the word class 'modal particles', had the following sub-classes: 1. simple modal, 2. negation words, 3. existential particles and 4. question particles and question adverbs. In the most recent version of his morphological database the word class 'modal particles' has the following sub-classes: modal particles 1 (epistemic particles), modal particles 2 (Modalfunktoren), modal particles 3 (emphasizing particles), modal particles 4 (focus particles) and modal 5 (existential particles).

30 Talstra (1994: 290-4) raises a number of questions in this regard in his review of Richter (1991). 
treated in the same way. In this regard the computer is of great help, since whenever similar phenomena are not treated consistently, the computer would require searches to be repeated unnecessarily. A good example in this regard was the need to refine the grammatical terminology and the rules that determine which items belong to particular categories. For this purpose structural linguistics was very helpful, since it provides criteria for describing linguistic data in terms of objectively defined criteria. This is the reason that Richter's databases can be useful for researchers with different theoretical frames of reference. When one, for example, does not agree with Richter that participle clauses are nominal clauses, or is of the opinion that hyh clauses should be considered as verbal clauses, this need not negatively influence the effectiveness of one's work with the databases. The only condition is that one should take the options Richter made into account.

As far as (2) is concerned, it in essence involves various objections that centre on the same topic, namely the theoretical status of Richter's grammatical model. It is said that this model is not clear and fundamentally flawed. ${ }^{31}$

Most of these objections are raised from a theoretical linguistic perspective. However, to appreciate the objections from this perspective, the following must be kept in mind. Theoretical linguistic models are often developed at a very abstract level, and are aimed at providing explanations of how language works as a human capacity. Such models seldom provide a comprehensive theoretical frame of reference for the description of individual languages. Grammarians of individual languages do use models from theoretical linguistics and try to apply them to better describe these languages. However, these concepts and insights (or models) can seldom account for all the data of individual languages. If this had been the case, it would have been easy to analyse and categorize all the data of individual languages in terms of such a model.

31 Disse (1998: 46) objects that the theoretical status of Richter's grammar is not clear. The reason for this objection is that Richter (1978: 10) calls for a new linguistic model for the description of $\mathrm{BH}$, but then takes only the most basic features of a structuralist approach into account for the development of his own theoretical frame of reference. Disse himself in the second part of his dissertation uses aspects of Richter's model.

Hardmeier (1991: 128f) characterizes Richter's model as a parole-grammar, which merely analyses and categorizes the variety of language uses in $\mathrm{BH}$ ('letztlich nur die Vielfalt der Sprachvorkommen typisiert und klassifiziert ...'). According to Hardmeier, when texts are described in terms of this model it results in a high degree of repetition. 
It is indeed true that Richter's approach, as far as his morphology, morphosyntax and sentence syntax are concerned, is the result of the eclectic use of insights from the theoretical linguistics of his day. Three concepts are dominant in this regards, the first is that of the identification of grammatical categories on account of the distribution properties of items at the same level of description. This type of implementation of insights of structuralist linguistics has in a sense gained a canonical status in the grammatical description of language. However, experiments by some of his students (e.g. Schweizer 1981 and Wagner 1989) in describing linguistic phenomena beyond the level of the clause by means of strict structuralist criteria must not be confused with Richter's own approach in this regard. He himself has confined himself up till now to the analysis and description of clause-level and inter-clause level phenomena. He fully acknowledges the importance of, but also complexities involved in the higher levels of description.

The second concept from theoretical linguistics that plays a significant role in Richter's approach to syntax is that of valency theory. The basic principle of this model, which Richter applies in his analysis and classification of clauses, also enjoys general acceptance by most grammarians of our day. ${ }^{32}$ The same can be said of a third concept Richter employs, viz. the distinction between the surface level and deep structure of a clause.

Each of these concepts are used by Richter because they have an instrumental value for his purposes, viz. to put the description of Biblical Hebrew on a more scientific footing. In no way does he implement or subscribe to the tenets of the broader theories from which he selected his instruments.

Richter does not claim that his instrumental model can provide for Biblical Hebrew (as a so-called dead language) grammatical descriptions that are more than observationally adequate. In other words, his grammatical description does not claim to modulate the

32 Vanoni (1993: 25f) points to the ways in which the valency model has been incorporated into other grammatical models, even those with content as their point of departure. There are also fresh attempts to link valency grammar and generative grammar (Steinitz 1992). Ágel (2000) highlights the role valency theory is playing in current linguistic theories. It has even been found that valency theory sheds light on the way language is acquired (Behrens 1999: 32.42ff). According to Behrens, and in contrast to earlier assumptions, in the process of language acquisition 'existing' semantic and syntactic rules are not applied to newly acquired vocabulary. Those rules are rather abstracted gradually and with some effort from holistically learnt occasional verb constructions. This means that the verb plays a pivotal role in the process of speech acquisition. 
speech competence of Biblical Hebrew speakers, nor contribute towards the explanation of human language capacity in the sense advocated by Chomsky. ${ }^{33}$ Richter modelled his databases in the light of the useful perspectives the modern linguistics of his day had to offer for a better description of the morphology, morphosyntax, clause syntax and semantics as well as the lexical semantics of Biblical Hebrew. If one tries to appreciate or criticize his work, one has to do so on the basis of whether his databases can do what they were intended for. One can only hope that they will soon be more freely available, in order on the one hand, to reveal the wealth of grammatical insights that underlies them and, on the other hand, to show the sophisticated, objectively testable, descriptions of Biblical Hebrew that can be accomplished with their help.

\section{BIBLIOGRAPHY}

Ágel, V. 2000. Valenztheorie. (Narr Studienbücher, Tübingen)

Bauer, H. and P. Leander. 1922. Historische Grammatik der hebräischen Sprache des Alten Testaments. (Halle; Reprint: Hildesheim 1962)

Beaugrande, R de. 1984. Text Production: Towards a Science of Composition. (Norwood)

Behrens, H. 1999. 'Was macht Verben zu einer besonderen Kategorie im Spracherwerb?', in: J. Meibauer and H. Rothweiler (eds) Das Lexikon im Spracherwerb (Uni-Taschenbücher 2039. Tübingen). 32-50

Disse, A. 1998. Informationsstruktur im Biblischen Hebraisch. 2 vols (ATSAT 55. St. Ottilien)

Eckhardt, W. 1987. Algorithmische Erkennung der Morphologie. (ATSAT 29. St. Ottilien)

Gross, W. 1996. Die Satzteilfolge im althebräischen Verbalsatz: Untersucht an den Bücher Dtn. Ri und 2Kön. (Tübingen)

Hardmeier, C. et al. (eds). 2000. Ad fontes! Quellen erfassen — lesen — deuten. Was ist Computerphilologie? (Amsterdam)

Irsigler, H. 1993. 'Großsatzformen im Althebräischen und die syntaktische Struktur der Inschrift des Königs Mescha von Moab', in H. Irsigler (ed), Syntax und Text (ATSAT 29. St. Ottilien). 81-121

Irsigler, H. 1997. 'Speech Acts and Intention in the "Song of the Vineyard" Isaiah 5:1-7', Old Testament Essays 10, 39-68

Nissim, U. 2000. Die Bedeutung des Ergehens. Ein Beitrag zu einem BiblischHebräischen Valenzlexikon am Beispiel von Ergehensverben. (ATSAT 65. St. Ottilien)

Rechenmacher, H. 1996. 'šabbat[t] - Nominalform und Etymologie', ZAH 9, 199-203

2002. 'Gott und das Chaos: Ein Beitrag zum Verständnis von Gen 1,1-3', $Z A W 114,1-20$

33 This Disse (1998: 46) also observes, despite his critique of Richter. 
2003. Wortfügungen in einer althebräischen Datenbank', $R B$ 110, 161-6

Riepl, Ch. 1996. 'Satz- und Metasatzbezeichnung in $\mathrm{BH}^{t}$ : Probleme, Lösungen und Änderungen', $R B 103,561-80$

- 1999. 'Wie wird Literatur berechenbar? Ein Modell zur rechnergestützten Analyse althebräischer Texte', Jahrbuch für Computerphilologie 1, 107-34

Richter, W. 1971. Exegese als Literaturwissenschaft: Entwurf einer alttestamentlichen Literaturtheorie und Methodologie. (Göttingen)

— 1978. Grundlagen einer althebräischen Grammatik: I. Das Wort (Morphologie).

(ATSAT 8. St. Ottilien)

1979. Grundlagen einer althebräischen Grammatik II. Die Wortfïgung (Morphosyntax). (ATSAT 10. St. Ottilien)

1980. Grundlagen einer althebräischer Grammatik: III. Der Satz (Satztheorie).

(ATSAT 13. St. Ottilien)

1983. Transliteration und Transkription: Objekt- und metasprachliche Metazeichensysteme zur Wiedergabe hebräischer Texte. (ATSAT 19. St. Ottilien)

- 1991. Biblica Hebraica transcripta. (ATSAT 33. St. Ottilien)

- 1996. Materialien einer althebräischen Datenbank: Die bibelhebräischen und

—aramäischen Eigennamen morphologisch und syntaktisch analysiert. (ATSAT 47.

St. Ottilien)

1998. Materialien einer althebräischen Datenbank: Nominalformen. (ATSAT

51. St. Ottilien)

1999. Althebräische Inschriften transkribiert. (ATSAT 52. St. Ottilien)

— 2002. 'Materialien einer althebräischen Datenbank: Verbalformen', in H. Irsigler (ed), Wer darf hinaufsteigen zum Berg JHWHs? (ATSAT 72. St. Ottilien). 305-32

Schwarz, C. 1982. 'Was ist ein "Adverb”?', Linguistsche Berichte 81, 61-5

Schweizer, H. 1981. Metaphorische Grammatik: Wege zur Integration von Grammatik und Textinterpretation in der Exegese. (ATSAT 15. St. Ottilien)

Seidl, Th. 1989. 'Die literaturwissenschaftliche Methode in der alttestamentlichen Exegese: Erträge - Erfahrungen - Projekte. Ein Überblick', Münchner Theologische Zeitschrift 40, 27-37

Specht, G. 1990. Wissenbasierte Analyse althebräischer Morphosyntax: Das Expertensystem AMOS. (ATSAT 35. St. Ottilien)

Steinitz, R. 1992. “Modern”: Argumentstruktur, "Traditionell”: Valenz — Versuch eines Brückenschlags', Linguistische Berichte 137, 33-44

Talstra, E.1994. 'Review of Richter 1991', JSS 33, 290-5

Talstra, E. and C. Sikkel. 2000. 'Genese und Kategorienentwicklung der WIVUDatenbank. Oder: ein Versuch, dem Computer Hebräisch beizubringen', in C. Hardmeier et al. (eds), Ad fontes! Quellen erfassen - lesen — deuten. Was ist Computerphilologie? (Amsterdam). 33-68

Van der Merwe, C.H.J. 1987. 'A Short Survey of Major Contributions to the Grammatical Description of Old Hebrew since 1800 AD', JNSL 13, 161-90

1989. 'Recent Trends in the Linguistic Description of Old Hebrew', JNSL 15, 217-41

1993. 'Particles and the Interpretation of the Old Testament texts', JSOT 60, $27-44$

— 1994. 'Discourse Linguistics and a Biblical Hebrew Grammar', in R.D. Bergen (ed.), Biblical Hebrew and Discourse Linguistics (Dallas). 13-49

1999. 'Towards a Better Understanding of Biblical Hebrew Word Order', JNSL 25, 277-300 
_ 2003. 'Some Recent trends in Biblical Hebrew Linguistics: a Few Pointers towards a More Comprehensive Model of Language Use', Hebrew Studies 44, 226-42

Van der Merwe, C.H.J., J.A. Naudé, and J.H. Kroeze. 1999. A Biblical Hebrew Reference Grammar. (Sheffield)

Vanoni, G. 1993. 'Fragen der Syntax und Semantik von Verbvalenzen im Althebräischen', in H. Irsigler (ed.), Syntax und Text (ATSAT 40. St. Ottilien). 2547

Vanoni, G. 1996. '“Was verursacht Reichtum?” und weitere Fragen zu Spr 15,16 - mit Hilfe der $\mathrm{BH}^{t}$ - Software zu beantworten versucht', Biblische Notizen 85, $70-88$.

Wagner, R. 1989. Textexegese als Strukturanalyse: Sprachwissenchaftliche Methode zur Erschliessung althebräischer Text am Beispiel des Visionsberichtes Jes 6,1-11. (ATSAT 32. St. Ottilien) 